\title{
$\beta$-casein Variants and Anti-oxidant Profiles of Milk of Siquijor Native Cattle (Bos taurus indicus L.) as Compared to those of Holstein Friesian $x$ Sahiwal Cattle
}

\author{
G. T. A. Cuevas ${ }^{\mathrm{a}, *}$, A. A. Angeles ${ }^{\mathrm{b}}$, F. E. Mercac ${ }^{\mathrm{c}}$, \& A. J. Salces ${ }^{\mathrm{d}}$ \\ ${ }^{a}$ Department of Chemistry, College of Arts and Sciences, University of the Philippines Visayas, \\ Miagao, Iloilo, 5023, Philippines \\ ${ }^{b}$ Dairy Training and Research Institute, College of Agriculture and Food Science, University of the Philippines Los \\ Baños, College, Laguna 4031, Philippines \\ 'Institute of Chemistry, College of Arts and Sciences, University of the Philippines Los Baños, \\ College, Laguna 4031, Philippines \\ ${ }^{\mathrm{d}}$ Animal Breeding Division, Institute of Animal Science, College of Agriculture and Food Science, University of the \\ Philippines Los Baños, College, Laguna 4031, Philippines \\ ${ }^{*}$ Corresponding author: gacuevas@up.edu.ph \\ (Received 03-08-2020; Revised 20-10-2020; Accepted 02-11-2020)
}

\begin{abstract}
The study aims to isolate, characterize, and evaluate the antioxidant activity of $\mathrm{A}^{1}$ and $\mathrm{A}^{2} \beta$-casein $(\beta-C N)$ variants from milk of Siquijor native cattle $(S N)$ and compare it to that of Holstein Friesian $x$ Sahiwal (HF). Four milk samples from SN and three milk samples from HF, collected at 60-90 days during the first and second parities, were used in this study. Caseins were isolated from the milk samples by isoelectric precipitation at $\mathrm{pH} 4.5$, urea denaturation, and SDS-PAGE. The fractions were quantified by Bradford assay. Antioxidant activity of the fractions was determined by DPPH scavenging assay. All the samples were analyzed using one-way ANOVA to determine the statistical difference. The concentrations of $\beta-\mathrm{CN}$ variants isolated from the milk of Siquijor native cattle and the milk of Holstein Friesian $x$ Sahiwal were not significantly different $(p>0.05)$. All of the casein samples exhibited DPPH scavenging activity with $\mathrm{A}^{2} \beta-\mathrm{CN}$ exhibiting significantly higher scavenging activity $(p<0.05)$. SN1 $\mathrm{A}^{2} \beta-\mathrm{CN}$ exhibited the highest DPPH scavenging activity at $5.298 \% \pm 0.17$ among all of the samples. These results indicate that $\mathrm{A}^{2} \beta-\mathrm{CN}$ may play a vital role in maintaining antioxidant homeostasis in the human body when the milk is consumed. These results also indicate the significance of $\mathrm{A}^{2} \beta-\mathrm{CN}$ in extending the shelf-life of milk and other dairy products. In conclusion, this study successfully fractionated and characterized both $A^{1}$ and $A^{2} \beta-C N$ variants in the milk of Siquijor native cattle and Holstein Friesian $x$ Sahiwal, with $A^{2} \beta-C N$ having higher antioxidant activity compared to $\mathrm{A}^{1} \beta-\mathrm{CN}$.
\end{abstract}

Keywords: milk; urea denaturation; $A^{1} \beta-C N ; A^{2} \beta-C N ; D P P H$ scavenging

\section{INTRODUCTION}

Beta-casein $(\beta-\mathrm{CN})$ is one of the most abundant proteins in the milk of dairy cattle. It has two main genotypes: the $\mathrm{A}^{1}$ and $\mathrm{A}^{2}$ genotypes. The difference in $\mathrm{A}^{1}$ and $\mathrm{A}^{2} \beta-\mathrm{CNs}$ is only in the amino acid at position $67 ; \mathrm{A}^{1}$ is histidine while $\mathrm{A}^{2}$ is proline (Givens et al., 2013; Kirk et al., 2017). The difference in one amino acid contributes to the difference in the properties and characteristics between the two $\beta-\mathrm{CN}$ variants. Healthy milk is reported to have high concentrations of $\mathrm{A}^{2}$ compared to $\mathrm{A}^{1} \beta-\mathrm{CN}$. Studies have shown that milk composed of predominantly $\mathrm{A}^{2} \beta-\mathrm{CN}$ is beneficial for the consumption of hypertensive individuals or individuals with cardiovascular disease (Dinesh et al., 2020). Milk rich in $\mathrm{A}^{2} \beta$-CN does not cause fat-build up in the blood vessels, unlike $\mathrm{A}^{1} \beta-\mathrm{CN}$ (Kaskous, 2020). Digestion of $\mathrm{A}^{1} \beta-\mathrm{CN}$ by gastric peptides released $\beta$-casomorphin 7 (BCM7), an oxidant of lipoproteins, which can lead to fat-build up in the blood vessels and eventually plaque formation (Boro et al., 2016; Jawale et al., 2017). The $\mathrm{A}^{2} \beta-\mathrm{CN}$ is also beneficial for lactose intolerant people because it can easily be digested, unlike $\mathrm{A}^{1} \beta-\mathrm{CN}$ (Jawale et al., 2017). Recent studies also reported that $A^{1}$ and $A^{2} \beta-C N s$ exhibited antioxidant activities that can be beneficial in the preservation of milk and the applications of milk as one of the most nutritious functional food (Petrat-Melin et al., 2015). Some of these amino acids and peptides exhibiting antioxidant activities that are present in $\mathrm{A}^{1}$ and $\mathrm{A}^{2} \beta-\mathrm{CN}$ are tyrosine, Ala-Val-Pro-Tyr-Pro-Gln-Arg $(\beta$-casein $\mathrm{f}(177-183))$, Lys-Val-Leu-Pro-Val-Pro-Glu-Lys $(\beta$-casein $\mathrm{f}(169-176))$, and Val-Leu-Pro-Val-Pro-Glu-Lys ( $\beta$-casein $\mathrm{f}(170-176))$ (Lucarini, 2017; Shazly et al., 2017).

The study focused on a native cattle breed from the island of Siquijor and Bohol, Philippines, which are smaller in stature compared to the other cattle breeds 
and have a low genetic relationship with the other native cattle in the country. Siquijor native cattle are predominantly taurine (subspecies of domesticated cattle originating in Western Asia) by descent named as Bos taurus indicus $L$. These cattle are grass fed in a farm in Bohol. Thus, the consumption of chemicals was minimized. Recent genetic studies showed the presence of $\mathrm{A}^{2}$ and $\mathrm{A}^{1} \beta-\mathrm{CN}$ genotypes in the cattle's hair DNA that is possibly translated to their milk. Because of this, there is a need to quantify and characterize the $\beta-C N$ variants in Siquijor native cattle to determine the levels of $A^{2} \beta-C N$ in its milk and to assess its health impacts in comparison to that of Holstein Friesian $x$ Sahiwal milk. This study was the first time that the $\beta-C N$ variants of Siquijor native cattle milk are fractionated and characterized by simple methods of urea denaturation and SDS-PAGE. This study will be the baseline for other studies focusing on the development of the quality, quantity, and health benefits of milk produced by Siquijor native cattle. The general objective of this study was to isolate, fractionate, quantify, and evaluate the DPPH scavenging activity of $\beta$-CN variants of milk samples from Siquijor native cattle and Holstein Friesian $x$ Sahiwal cattle.

\section{MATERIALS AND METHODS}

About one liter of milk sample was collected from four Siquijor native cattle from a farm in Bohol, Philippines, last February 1, 2018. On the other hand, three Holstein Friesian $x$ Sahiwal cattle milk samples were collected from Dairy Training and Research Institute (DTRI) at the University of the Philippines Los Baños (UPLB) last April 30, 2018. Table 1 summarized the inclusion criteria for the sampling of Siquijor native cattle milk and Holstein Friesian x Sahiwal milk. Both the Siquijor Native cattle milk and the Holstein Friesian $x$ Sahiwal milk were transported to the Institute of Chemistry, UPLB. The samples were stored in $1 \mathrm{~L}$ Nature Spring bottle (A.C. Cortes, Avenue, Cambaro, Mandaue City, Cebu, Philippines) and frozen in a $-20^{\circ} \mathrm{C}$ freezer until further analysis.

\section{Isolation of Casein from Skim Milk}

The isolation of the caseins was based on the procedure of Thekkilaveedu et al. (2019). One hundred twenty $\mathrm{mL}$ of cattle milk was used for the isolation of casein. The $120 \mathrm{~mL}$ sample was divided into 3 trials at $40 \mathrm{~mL}$ each trial. The milk samples were defatted first by centrifugation at $10,500 \mathrm{rpm}$ for $45 \mathrm{~min}$ at $4^{\circ} \mathrm{C}$. Casein samples were isolated by isoelectric precipitation at $\mathrm{pH}$ 4.5 by adding $10 \%$ acetic acid solution dropwise. The samples were centrifuged at 10,500 rpm for $45 \mathrm{~min}$ at $4^{\circ} \mathrm{C}$. The resulting supernatant was decanted, and the precipitate was collected. The casein samples were then washed twice with acidic water $(\mathrm{pH} 4)$ and was centrifuged. The casein samples were collected after centrifugation while the supernatant was discarded. The isolated caseins were dialyzed in buffer $(0.02 \mathrm{M}$ phosphate buffer $\mathrm{pH}$ 8.6) using a dialysis bag (average flat width 25 $\mathrm{mm}$, Merck) in water for $24 \mathrm{~h}$. The casein samples were freeze dried and stored in $25 \mathrm{~mL}$ falcon tubes.

\section{Detection of Casein with Sodium Dodecyl Sulfate Polyacrylamide Gel Electrophoresis (SDS-PAGE)}

The SDS-PAGE analysis was based on the procedure of Jan et al. (2016). Dried casein samples were redissolved in water. One molar of $\mathrm{NaOH}$ was added to the casein samples to adjust the $\mathrm{pH}$ to 7.5. The casein concentration was determined by Bradford Assay. Briefly, $0.350 \mathrm{mg} / \mathrm{mL}$ casein samples were mixed 1:4 (v/v) with urea denaturing solution (8 M urea, $165 \mathrm{mM}$ Tris, 44 $\mathrm{mM}$ sodium citrate, and $0.3 \% \mathrm{v} / \mathrm{v}$-mercaptoethanol). Twelve percent of gel was used for SDS-PAGE analysis. About $5 \mu \mathrm{L}$ of samples were transferred in Eppendorf tubes and added with $10 \mu \mathrm{L}$ of sample buffer to make a ratio of 1:2 (v/v). Samples were heated in a hot water bath $\left(95^{\circ} \mathrm{C}\right)$ for $5 \mathrm{~min}$. About $2-3 \mu \mathrm{L}$ of samples $(0.350$ $\mathrm{mg} / \mathrm{mL}$ ) and marker ( $\beta$-casein from bovine milk $\geqq 98 \%$ purity) were loaded to the gel. The run time was $80 \mathrm{~min}$ at $110 \mathrm{~V}$. After the run, the gels were removed and were stained using a staining solution (1 g Coomassie blue + $50 \%$ methanol $+10 \%$ acetic acid $+40 \%$ water $)$ overnight. The samples were destained the following day with destaining solution $(50 \%$ methanol $+10 \%$ acetic acid + $40 \%$ water). The separated proteins were characterized based on their molecular weights. The samples were then extracted from the gel, freeze dried, and reconstituted with $1.5 \mathrm{M}$ Tris- $\mathrm{HCl}$ buffer $\mathrm{pH} 7.4$ in preparation for Bradford assay to determine the concentration of the casein extracts and for the DPPH scavenging assay.

Table 1. Inclusion criteria in terms of cattle lactation days for the collection of milk samples from Siquijor native cattle and Holstein Friesian $x$ Sahiwal cattle

\begin{tabular}{ccccc}
\hline Samples & Cattle code & Collection period & Sample volume & Inclusion criteria \\
\hline SN1 & 11 & February 1, 2018 & $1000 \mathrm{~mL}$ & 1 st parity at 90 d \\
SN2 & 751 & February 1, 2018 & $1000 \mathrm{~mL}$ & 1 st parity at $90 \mathrm{~d}$ \\
SN3 & 50 & February 1, 2018 & $1000 \mathrm{~mL}$ & 1 st parity at $90 \mathrm{~d}$ \\
SN4 & 483 & February 1, 2018 & $1000 \mathrm{~mL}$ & 1 st parity at $90 \mathrm{~d}$ \\
HF1 & 2106 & April 30, 2018 & $500 \mathrm{~mL}$ & 1 st parity at $81 \mathrm{~d}$ \\
HF2 & 2010 & April 30, 2018 & $500 \mathrm{~mL}$ & 1 st parity at $66 \mathrm{~d}$ \\
HF3 & 2062 & April 30, 2018 & $500 \mathrm{~mL}$ & 2nd parity at 66 d \\
\hline
\end{tabular}

Note: $\mathrm{SN}=$ Siquijor native cattle; $\mathrm{HF}=$ Holstein Friesian $\times$ Sahiwal. 


\section{Determination of Casein Concentration}

The protein concentration was determined by Bradford Assay with bovine serum albumin (BSA) as a standard (Kielkopf et al., 2020). Standards were prepared from Bovine Serum Albumin (BSA) by serial dilutions. Standard solutions were prepared with concentrations ranging from 125 to $2500 \mu \mathrm{g} / \mathrm{mL}$. Two hundred fifty $\mu \mathrm{L}$ Bradford reagent (100 g Coomassie brilliant blue G-250 + 5\% 95\% ethanol + 10\% 85\% (v/v) phosphoric acid $+85 \%$ water) was added on every $300 \mu \mathrm{L}$-capacity microtiter wells. To the wells, $5 \mu \mathrm{L}$ of standards (125, 250, 500, 1000, 1500, 2000, and $2500 \mu \mathrm{g} / \mathrm{mL}$ ) and samples were added and mixed thoroughly. The microtiter plate was placed inside the UV-Vis spectrophotometer and absorbances of the samples were read at $595 \mathrm{~nm}$. The $\beta$-casein sample concentration was calculated from the standard curve equation.

\section{Antioxidant Activity of $\alpha-, A^{1} \beta-$, and $A^{2} \beta$-Casein}

The 2,2-Diphenyl-1-picrylhydrazyl (DPPH) antioxidant (powder, $\geqq 90 \%$, Merck) assay was based on the method of Rival et al. (2001). Casein samples previously extracted from the gel were used in this assay. The concentrations of the casein extracts were kept constant throughout the assay. About $25 \mu \mathrm{L}$ of casein extracts $(0.175 \mathrm{mg} / \mathrm{mL})$ were mixed with $75 \mu \mathrm{L}$ distilled water to obtain a $100 \mu \mathrm{L}$ sample solution. About $2.9 \mathrm{~mL}$ of 0.0004 $\mathrm{M}$ DPPH solution was added to the sample solutions and were subjected to vortex mixing. After vortex mixing, the casein samples were incubated in a dark place for 30 minutes at $30^{\circ} \mathrm{C}$ to allow the reaction to proceed. Absorbance was measured at $517 \mathrm{~nm}$ using a UV/Vis Spectrophotometer. The DPPH radical scavenging activity of $0.050 \mathrm{mg} / \mathrm{mL}$ ascorbic acid was also measured as a positive control. Buffer (1.5M Tris- $\mathrm{HCl} \mathrm{pH} 7.4)$ was used as a negative control. To measure the \% radical scaveng- ing activity, the absorbance of the DPPH solution was also read spectrophotometrically at $517 \mathrm{~nm}$.

\section{Statistical Analysis}

The experiments were performed in triplicates. Data on the concentration and \% radical scavenging activity of the three casein fractions were analyzed by one-way ANOVA using the statistical analysis software (SPSS Statistics 17.0) between the milk of Siquijor native cattle and the milk of Holstein Friesian x Sahiwal cattle. Samples were also compared to positive and negative controls by Paired T-test (Gomez \& Gomez, 1984).

\section{RESULTS}

The modified SDS-PAGE done in this study separated the $\beta-\mathrm{CN}$ variants and other caseins from each other (Figure 1). The standard $\beta-\mathrm{CN}$ used in the study has an estimated molecular weight of $23-24 \mathrm{kDa}$, as is presented in Figure 1. All samples exhibited two distinct bands around $23.5 \mathrm{kDa}$ similar to the standard, which indicated that all samples contain two $\beta-\mathrm{CN}$ variants, which were probably the $\mathrm{A}^{1}$ and $\mathrm{A}^{2}$ variants. All samples also contain $\alpha-\mathrm{CN}$ since a distinct band can also be seen at $26 \mathrm{kDa}$ based on the marker. A fainted band around 15-20 kDa was also seen in SN1 but cannot be seen in the other samples, which corresponds to $\kappa$-casein. Fainted bands can also be seen below $15 \mathrm{kDa}$ which correspond to $\beta-\lg$ and $\alpha$-la which were present in all of the samples. The average percentage yields of $\alpha, \mathrm{A}^{1}$, and $\mathrm{A}^{2}$ $\beta$-CN were $57.87 \%, 61.06 \%$, and $50.33 \%$, respectively.

Figure 2 shows the concentrations of the fractionated caseins. One-way ANOVA showed that there was no significant difference in the concentrations of the three isolated caseins among the four Siquijor native cattle milks ( $p>0.05)$. On the other hand, no significant difference was also observed in the concentrations of the

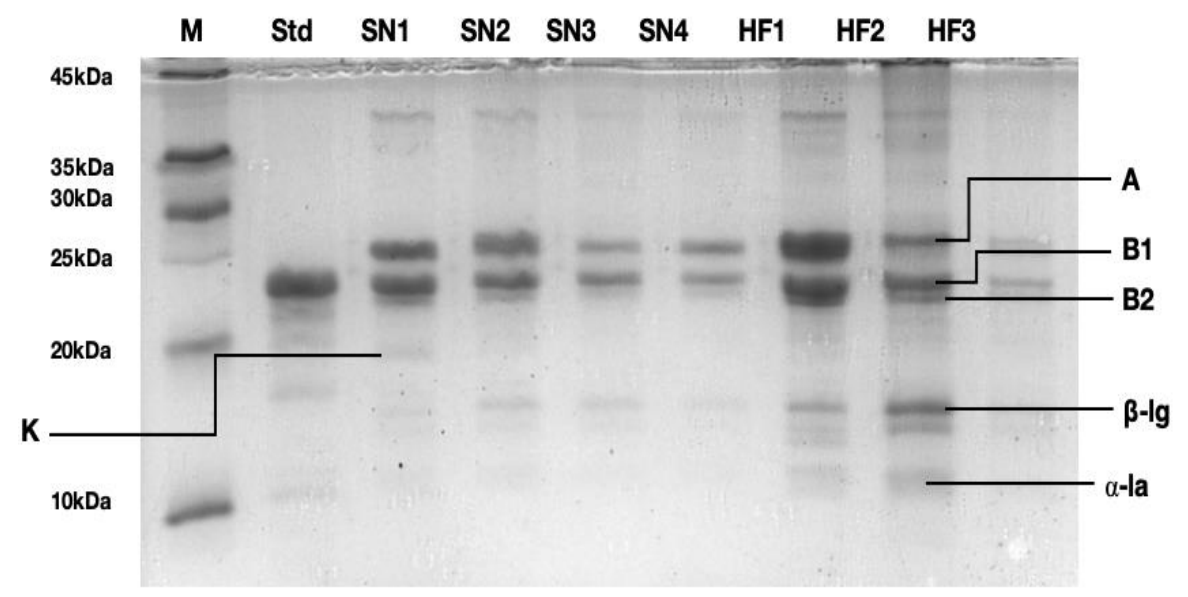

Figure 1. Electrophoretic separation of whole casein fractions from milk of Siquijor native cattle (SN) and Holstein Friesian x Sahiwal (HF) cattle. Standard bovine milk $\beta$-casein is shown in line $2(\mathrm{Std})$. Molecular marker (M) was also used to estimate the molecular weight of individual caseins. Beta-casein fraction from milk of both Siquijor native cattle and Holstein Friesian $x$ Sahiwal cattle was separated into two bands, band 1 (B1) and band 2 (B2), corresponding to beta casein $\mathrm{A}^{1}$ and $\mathrm{A}^{2}$, respectively. Alpha-casein $(\mathrm{A})$, kappa-casein $(\mathrm{K}), \beta$-lactoglobulin $(\beta-\mathrm{lg})$, and $\alpha$-lactalbumin ( $\alpha$-la) are also shown. 
three casein fractions among the three Holstein Friesian $x$ Sahiwal milk ( $>0.05)$. One-way ANOVA showed no significant difference in the concentrations of the casein fractions between Siquijor native cattle and Holstein Friesian x Sahiwal milk ( $p>0.05)$. No significant difference was observed among the concentrations of $\alpha-C N$ in all of the milk samples ( $p>0.05)$. No significant difference was also observed among the concentrations of $\mathrm{A}^{1}$ $(p>0.05)$ and $A^{2}(p>0.05) \beta-C N$ in all of the milk samples. These results imply that the milk of Siquijor native cattle and Holstein Friesian x Sahiwal cattle have comparable concentrations of major caseins.

SN1 $A^{2} \beta-C N$ exhibited the highest DPPH scavenging activity at $5.298 \pm 0.17 \%$, as shown in Table 2. SN3 $\alpha-\mathrm{CN}$ has a significantly higher $(\mathrm{p}<0.05) \mathrm{DPPH}$ scavenging activity compared to SN1, SN4, HF1, HF2, and HF3 but is comparable to that of SN2 (Table 2). SN4 $\alpha-C N$ also has a significantly $(p<0.05)$ higher DPPH scavenging activity compared to HF1 but is comparable to the DPPH scavenging activities of SN1, HF2, and HF3. SN4 and HF2 $A^{1} \beta-C N$ have significantly higher $(\mathrm{p}<0.05) \mathrm{DPPH}$ scavenging activities compared to those of SN1, SN2, SN3, and HF3 but are comparable to the activity of HF1. $A^{1} \beta-C N$ of $H F 1$ have a significantly higher $(\mathrm{p}<0.05) \mathrm{DPPH}$ scavenging activity compared to those of SN1, SN2, and HF3 but is comparable to that of SN3. The $A^{1} \beta-C N$ in the milk of SN1, SN2, and HF3 cows all have comparable DPPH scavenging activity. The $\mathrm{A}^{2} \beta-\mathrm{CN}$ in milk of SN1 cows have a significantly higher $(p<0.05)$ DPPH scavenging activity compared to the rest of the samples. Comparison of the \% DPPH scavenging activities of the samples to that of 0.05 $\mathrm{mg} / \mathrm{mL}$ ascorbic acid showed significant differences $(p<0.05)$. This is understandable since ascorbic acid is a highly active antioxidant. No DPPH inhibition was observed from the negative control (1.5M Tris- $\mathrm{HCl}$ buffer $\mathrm{pH} 7.4)$.

\section{DISCUSSION}

The dialysis of casein micelles progressively solubilized colloidal $\mathrm{Ca}^{2+}$ and inorganic phosphate in the solution, which disaggregated the casein micelles (Aoki et al., 1988). The reduction in colloidal inorganic phosphate during dialysis is the result of the decreased in the casein aggregates cross-linked by colloidal calcium phosphate $(\mathrm{CCP})$. The dialysis breaks the linkage between the caseins and the inorganic phosphate constituent.

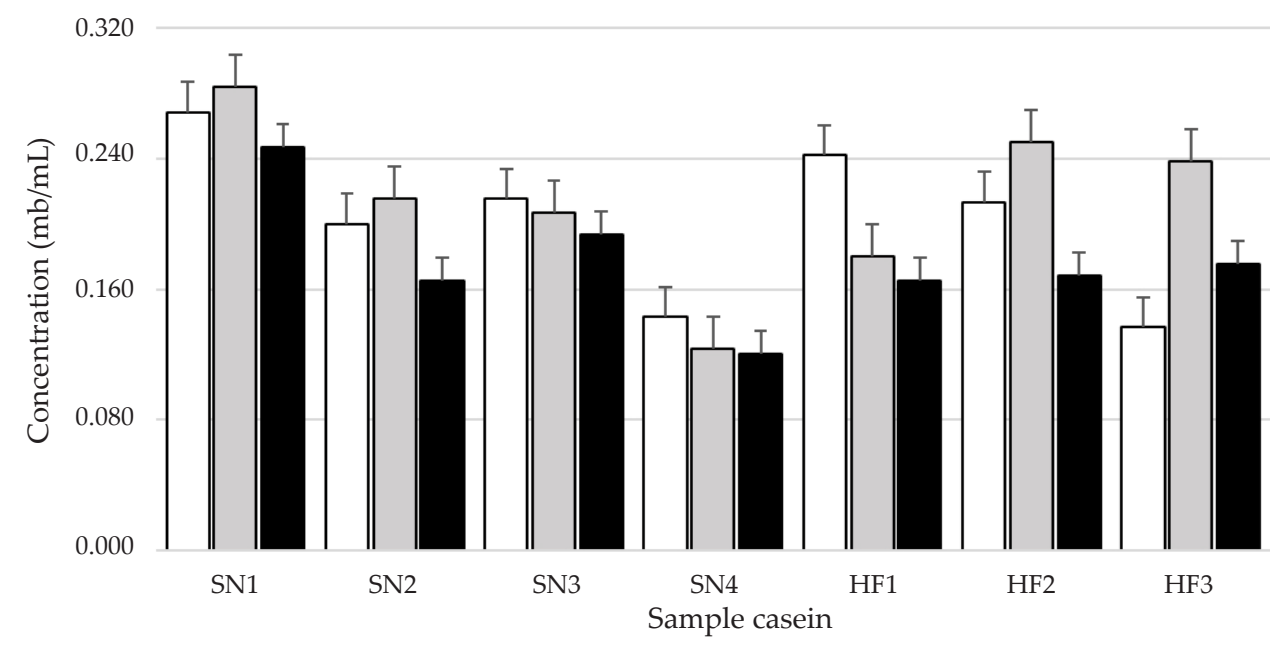

Figure 2. Average concentrations of isolated caseins from milk of Siquijor Native cattle (SN) and Holstein Friesian $\times$ Sahiwal (HF); $\square=\alpha$-casein; $\square=\beta$-casein A1; $\square=\beta$-casein A2.

Table 2. Average DPPH Scavenging activity of isolated caseins from milk of Siquijor Native cattle (SN) and Holstein Friesian x Sahiwal (HF) at constant concentration $(0.175 \mathrm{mg} / \mathrm{mL})$

\begin{tabular}{lccc}
\hline & \multicolumn{3}{c}{ \% DPPH radical scavenging activity } \\
\cline { 2 - 4 } & $\alpha-C N$ & $A^{1} \beta-C N$ & $A^{2} \beta-C N$ \\
\hline SN1 & $3.727 \pm 0.20^{c}$ & $3.621 \pm 0.12^{c}$ & $5.378 \pm 0.17^{\mathrm{a}}$ \\
SN2 & $4.552 \pm 0.16^{\mathrm{c}}$ & $3.887 \pm 0.17^{\mathrm{c}}$ & $4.766 \pm 0.12^{\mathrm{b}}$ \\
SN3 & $4.739 \pm 0.17^{\mathrm{a}}$ & $3.940 \pm 0.20^{\mathrm{c}}$ & $4.899 \pm 0.05^{\mathrm{b}}$ \\
SN4 & $4.047 \pm 0.26^{\mathrm{b}}$ & $4.712 \pm 0.16^{\mathrm{a}}$ & $4.846 \pm 0.12^{\mathrm{b}}$ \\
HF1 & $3.408 \pm 0.28^{\mathrm{c}}$ & $4.393 \pm 0.16^{\mathrm{c}}$ & $4.712 \pm 0.16^{\mathrm{b}}$ \\
HF2 & $3.834 \pm 0.24^{\mathrm{c}}$ & $4.446 \pm 0.20^{\mathrm{c}}$ & $4.872 \pm 0.08^{\mathrm{b}}$ \\
HF3 & $3.727 \pm 0.20^{\mathrm{c}}$ & $3.514 \pm 0.16^{\mathrm{b}}$ & $4.606 \pm 0.12^{\mathrm{b}}$ \\
Positive control (0.05 mg/mL ascorbic acid) & & $93.317 \pm 0.12$ & \\
Negative control (1.5 M Tris-HCl pH 7.4) & & $0.00 \pm 0.00$ & \\
\hline
\end{tabular}

Note: SN= Siquijor native cattle (4 sample sets); HF= Holstein Friesian x Sahiwal (3 sample sets). Means in the same column/row with different superscripts differ significantly $(\mathrm{p}<0.05)$. 
The strength of binding of caseins to the casein micelles is in the order of $\alpha_{\mathrm{s2}}->\alpha_{\mathrm{s} 1}>>\beta->\kappa-C N$ (Aoki et al., 1988; $\mathrm{Xu}$ et al., 2016). This is dependent on the number of ester phosphate present in the casein molecules. Thus, $\beta$ - (5 phosphate molecules linked to serine residue) and $\kappa-C N$ (1 phosphate molecules linked to serine residue) micelles are disaggregated faster compared to $\alpha_{\mathrm{s} 2}$ and $\alpha_{\mathrm{s} 1}$ (10 phosphates linked to serine residue) (Huppertz et al., 2017).

The results of the electrophoresis were in good agreement with the results of Salmen et al. (2011), who reported the molecular weight of $\alpha$-casein and $\beta-\mathrm{CN}$ at $25.3 \mathrm{kDa}$ and $22 \mathrm{kDa}$, respectively. Salmen et al. (2011) also reported the presence of $\kappa-\mathrm{CN}$ around 15-20 kDa. The percent purity of the isolated caseins was not analyzed in this study; however, most studies reported that the most abundant caseins found around 22 to 26 $\mathrm{kDa}$ are $\beta-\mathrm{CN}$ and $\alpha-\mathrm{CN}$, respectively (Bijl et al., 2018). Whitney et al. (1976) reported that no other milk proteins are present at 22 to $26 \mathrm{kDA}$ other than $\alpha$ and $\beta-\mathrm{CN}$. In SDS-PAGE, proteins are separated based on the polypeptide chain length. Sodium dodecyl sulfate (SDS) is a detergent that binds to the casein backbone at a constant molar ratio (1:1). SDS cleaves disulfide bonds in the casein structure, which is responsible for the proper folding of proteins. This causes the unfolding of caseins into linear chains with a negative charge that migrates faster due to less resistance from the gel matrix. The $\beta-C N$ variants also undergone urea denaturation. Urea can act on caseins via a direct method. Urea molecules hydrogen bonds with the peptide groups in caseins which weakens the intermolecular forces within the casein molecule, thus, disrupting the secondary and tertiary structures of the casein micelles (Duarte-Vázquez et al., 2018). This hastens the denaturation process, which leaves the amino acid sequence of the caseins. Indirect denaturation of the casein by urea is also possible. Urea affects the properties of the solvent in which the caseins are immersed. Urea changes the structure and hydrodynamics of the solvent (water), which results in the destabilization of the internal interaction of the caseins and water. This condition results in the unraveling of the casein micelles (Atamer et al., 2017).

Beta-casein is separated into two bands, which can be seen in Figure 1 (B1 and B2). These bands correspond to $A^{1}$ and $A^{2} \beta$-casein variants. They differ only in the amino acid at position $67 ; \mathrm{A}^{1}$ is histidine while $\mathrm{A}^{2}$ is proline (Givens et al., 2013). $\mathrm{A}^{2} \beta-\mathrm{CN}$ has a likelihood to form polyproline II (PPII) helix secondary structures compared to that of the $\mathrm{A}^{1}$ variant since it has a higher concentration of proline in its amino acid sequence (Massella et al., 2017). The additional proline at position 67 enhances the PPII helix formation, which can alter the protein's structural dynamics and self-assembly behavior (O'Brien et al., 2020). Exploiting these differences, the separation of the two variants is possible using chemical interventions. The relative mobilities (Rf) of $\mathrm{A}^{1}$ and $\mathrm{A}^{2}$ $\beta-\mathrm{CN}$ are $0.513 \pm 0.025$ and $0.527 \pm 0.027$, respectively. The additional proline in the $\mathrm{A}^{2}$ variant makes it shorter in length compared to the $\mathrm{A}^{1}$ variant. Therefore, it can travel the SDS-PAGE gel much faster. The trend of the RF values of $A^{1}$ and $A^{2} \beta-C N$ in this study is comparable to that of Duarte-Vázquez et al. (2018), who reported that the $R f$ value of the $A^{2}$ variant $(R f=0.217 \pm 0.005)$ is higher compared to that of the $\mathrm{A}^{1}$ variant $(\mathrm{Rf}=0.203 \pm$ 0.005).

The isolated $\beta-\mathrm{CN}$ variants exhibited antioxidant activity. The antioxidant activity and capacity of a compound depend on the rate of reaction between the antioxidant and the reactive species. The faster the rate of reaction, the stronger the antioxidant activity. The concentration ratio between the antioxidant and reactive species also affects the antioxidant activity. The higher the concentration of the antioxidant compared to the reactive species, the stronger the antioxidant activity (Silveira et al., 2017). Due to the lesser concentrations of the isolated caseins, the antioxidant activity of both $\mathrm{A}^{1}$ and $\mathrm{A}^{2} \beta-\mathrm{CN}$ were considered weak compared to that of the positive control, which is Vitamin C. There is a possible increase in the antioxidant activity of the sample if the concentrations will be increased.

The antioxidant activity of caseins has a variety of possible mechanisms. One possible mechanism is the antioxidant activity of specific amino acids present in the $\beta-\mathrm{CN}$. These amino acids have the ability to scavenge free radical species such as DPPH. Tyrosine, which is abundant in caseins, exhibits free radical scavenging activity (Rival et al., 2001; Shazly et al., 2017). Other amino acids with potential radical scavenging activity are tryptophan, histidine, lysine, and methionine (Chen et al., 1998; Khan et al., 2019). Peptides such as Ala-ValPro-Tyr-Pro-Gln-Arg ( $\beta$-casein f(177-183)), Lys-Val-LeuPro-Val-Pro-Glu-Lys ( $\beta$-casein $\mathrm{f}(169-176))$, and Val-LeuPro-Val-Pro-Glu-Lys $(\beta$-casein $\mathrm{f}(170-176)$ ) all exhibited DPPH radical scavenging activity (Lucarini, 2017). Chen et al. (1998) explained that His residues and their position relative to the $\mathrm{N}$-terminal might be important in the radical scavenging activity of caseins. Cysteine and proline also showed radical scavenging activities (Hamin Neto et al., 2019). These amino acids and amino acid sequences mentioned above are all present in both $\mathrm{A}^{1}$ and $\mathrm{A}^{2} \beta-\mathrm{CN}$.

Other possible factors can also be caused for the variation of the antioxidant activity exhibited by the $\beta-\mathrm{CN}$ variants. The lactation stage in which the milk sample was collected can be a factor to the difference in DPPH scavenging activity of the samples. However, the study cannot confirm this assumption since the collection of samples throughout lactation was not performed in this study. The results of this study indicate that $A^{2}$ $\beta-\mathrm{CN}$ may play a vital role in maintaining antioxidant homeostasis in the human body when consumed. The shelf life of milk may also be prolonged due to the antioxidative properties of $\mathrm{A}^{2} \beta-\mathrm{CN}$, which may prevent lipid oxidation within the milk, and therefore, improved the overall quality of milk and other dairy products (Castillo et al., 2013). On the other hand, $\mathrm{A}^{1} \beta-C N$ is somehow harmful rather than beneficial because it releases BCM7 when digested by gastric peptides in the stomach. BCM7 is believed to oxidize low density lipoproteins (LDL), making them more reactive with the surrounding tissues, thus, causing inflammation. This inflammation can cause plaque formation in blood vessels that will eventually lead to atherosclerosis and other 
cardiovascular diseases (Boro et al., 2016; Dinesh et al., 2020).

HPLC and amino acid sequencing are recommended in order to further characterize the $\beta-\mathrm{CN}$ variants in both milk samples. Comparison of the concentrations of $\mathrm{A}^{1}$ and $\mathrm{A}^{2} \beta-\mathrm{CN}$ in milk through the lactation stage of Siquijor native cattle is also essential for future studies. Determination of the effects of diet on $A^{1}$ and $A^{2} \beta-C N$ should also be determined.

\section{CONCLUSION}

The presence of $A^{1}$ and $A^{2} \beta-C N$ in the milk of Siquijor Native cattle and Holstein Friesian $x$ Sahiwal was validated by this study for the first time with the use of urea denaturation and SDS-PAGE, which provided evidence that both $\mathrm{A}^{1}$ and $\mathrm{A}^{2} \beta-C N$ genotype in the cattle's hair DNA was translated to the milk. The concentrations of the casein fractions in the milk obtained from Siquijor native cattle were comparable to that obtained from Holstein Friesian $x$ Sahiwal cattle indicating that casein constituent does not vary significantly from one breed to another. Furthermore, $\mathrm{A}^{2} \beta-\mathrm{CN}$ has a higher and greater DPPH scavenging activity compared to $\mathrm{A}^{1} \beta-\mathrm{CN}$, thus, implying the importance of $\mathrm{A}^{2} \beta-\mathrm{CN}$ in maintaining the quality of bovine milk.

\section{CONFLICT OF INTEREST}

We certify that there is no conflict of interest with any financial, personal, or other relationships with other people or organization related to the material discussed in the manuscript.

\section{ACKNOWLEDGEMENT}

This work was supported by the Department of Science and Technology-ASTHRDP scholarship grant. We thank Dr. Mary Ann O. Torio for providing the UV/ Vis Spectrophotometry Instrument used in this study. We also thank University of the Philippines Los BañosInstitute of Plant Breeding for providing the miniprotean tetra system used in the SDS-PAGE experiment.

\section{REFERENCES}

Aoki, T., N. Yamada, \& Y. Kako. 1988. Dissociation during dialysis of casein aggregates cross-linked by colloidal calcium phosphate in bovine casein micelles. J. Dairy Sci. 55:189195. https://doi.org/10.1017/s0022029900026017

Atamer, Z., A. E. Post, T. Schubert, A. Holder, R. M. Boom, \& J. Hinrichs. 2017. Bovine $\beta$-casein: Isolation, properties and functionality. A review. Int. Dairy. J. 66:115-125. https:// doi.org/10.1016/j.idairyj.2016.11.010

Bijl, E., T. Huppertz, H. van Valenberg, \& C. Holt. 2018. A quantitative model of the bovine casein micelle: ion equilibria and calcium phosphate sequestration by individual caseins in bovine milk. Eur. Biophys. J. 48:45-59. https:// doi.org/10.1007/s00249-018-1330-2

Boro, P., B. C. Naha, D. P. Saika, \& C. Prakash. 2016. A ${ }^{1}$ and $\mathrm{A}^{2}$ milk and its impact on human health. Int. J. Sci. 7:1-5.

Castillo, C., V. Pereira, A. Abuelo, \& J. Hernández. 2013. Effect of supplementation with antioxidants on the quality of bovine milk and meat production. Sci. World J. 2013:1-8. https://doi.org/10.1155/2013/616098

Chen, H. M., K. Muramoto, F. Yamauchi, K. Fujimoto, \& K. Nokihara. 1998. Antioxidative properties of histidine-containing peptides designed from peptide fragments found in the digests of a soybean protein. J. Agri. Food Chem. 46:49-53. https://doi.org/10.1021/jf970649w

Dinesh, M., D. Sahoo, J. C. Thakor, H. S. Yadav, R. Manikandan, J. Keerthana, A. Muthukumar, R. Pradeep, \& M. Sahoo. 2020. $A^{1}$ and $A^{2}$ Milk: Truth vs. Hype. A Magazine of Agriculture and Allied Sciences. 3:6-13.

Duarte-Vázquez, M. A., C. R. Garcia-Ugalde, B. E. Alvarez, L. M. Villegas, B. E. Garcia-Almendarez, J. L. Rosado, \& C. Regalado. 2018. Use of urea-polyacrylamide electrophoresis for discrimination of $\mathrm{A}^{1}$ and $\mathrm{A}^{2}$ beta casein variants in raw cow's milk. J. Food Sci. Technol. 55:1942-1947. https:// doi.org/10.1007/s13197-018-3088-z

Givens, I., P. Aikman, T. Gibson, \& R. Brown. 2013. Proportions of $A 1, A 2, B$ and $C \beta$-casein protein variants in retail milk in the UK. Food Chem. 139:549-552. https://doi.org/10.1016/j. foodchem.2013.01.115

Gomez, K. A. \& A. A. Gomez. 1984. Statistical Procedures for Agricultural Research. $2^{\text {nd }}$ ed. John Wiley and Sons, New York.

Hamin Neto, Y. A. A., J. C. Rosa, \& H. Cabral. 2019. Peptides with antioxidant properties identified from casein, whey, and egg albumin hydrolysates generated by two novel fungal proteases. Prep. Biochem. Biotechnol. 49:639-648. https://doi.org/10.1080/10826068.2019.1566147

Huppertz, T., I. Gazi, H. Luyten, H. Nieuwenhuijse, A. Alting, \& E. Schokker. 2017. Hydration of casein micelles and caseinates: Implications for casein micelle structure. Int. Dairy J. 74:1-11. https://doi.org/10.1016/j.idairyj.2017.03.006

Jan, S. A., Z. K. Shinwari, M. A. Rabbani, S. H. Shah, M. I. Ibrahim, \& M. Ilyas. 2016. Optimization of an efficient SDS-PAGE protocol for rapid protein analysis of Brassica rapa. J. Bio. Envi. Sci. 9:17-24.

Jawale, B., A. Kaluskar, J. Garde, \& S. Sabonis. 2017. “The Reality of the White" A1 vs A2 Milk - A Critical Review. Int. J. Sci. Res. 6:1844-1846.

Kaskous, S. 2020. A1- and A2- milk and their effect on human health. J. Food Eng. Technol. 9:15-21. https://doi. org/10.32732/jfet.2020.9.1.15

Khan, I. T., M. Nadeem, M. Imran, R. Ullah, M. Ajmal, \& M. H. Jaspal. 2019. Antioxidant properties of milk and dairy products: A comprehensive review of the current knowledge. Lipids Health Dis. 18:41. https://doi.org/10.1186/ s12944-019-0969-8

Kielkopf, C. L., W. Bauer, \& I. L. Urbatsch. 2020. Bradford assay for determining protein concentration. Cold Spring Harb. Protoc. 4:136-138. https://doi.org/10.1101/pdb.prot102269

Kirk, B., J. Mitchell, M. Jackson, F. Amirabdollahian, O. Alizadehkhaiyat, \& T. Clifford. 2017. A $^{2}$ milk enhances dynamic muscle function following repeated sprint exercise, a possible ergogenic aid for $\mathrm{A}^{1}$-protein intolerant athletes?. Nutrients. 9:1-14. https://doi.org/10.3390/nu9020094

Lucarini, M. 2017. Bioactive peptides in milk: From encrypted sequences to nutraceutical aspects. Beverages. 3:41. https:// doi.org/10.3390/beverages3030041

Massella, E., S. Piva, F. Giacometti, G. Liuzzo, A. V. Zambrini, \& A. Serriaino. 2017. Evaluation of bovine beta casein polymorphism in two dairy farms located in northern Italy. Ital. J. Food Saf. 6:6904. https://doi.org/10.4081/ ijfs.2017.6904

O’Brien, K. T., C. Mooney, C. Lopez, G. Pollastri, \& D. C. Shields. 2020. Prediction of polyproline II secondary structure propensity in proteins. R. Soc. Open Sci. 7:191239. https://doi.org/10.1098/rsos.191239

Petrat-Melin, B., P. Andersen, J. T. Rasmussen, N. A. Poulsen, L. B. Larsen, \& J. F. Young. 2015. In vitro digestion of 
purified $\beta$-casein variants $\mathrm{A}^{1}$ and $\mathrm{A}^{2}, \mathrm{~B}$, and I: Effects on antioxidant and angiotensin-converting enzyme inhibitory capacity. J. Dairy Sci. 98:15-26. https://doi.org/10.3168/ jds.2014-8330

Rival, S. G., C. G. Boeriu, \& H. J. Wichers. 2001. caseins and casein hydrolysates. 2. antioxidative properties and relevance to lipoxygenase inhibition. J. Agri. Food Chem. 49:295-302. https://doi.org/10.1021/jf0003911

Salmen, S. H., H. Abu-Tabrboush, A. A. Al-Saleh, \& A. A. Metwalli. 2011. Amino acids content and electrophoretic profile of camel milk casein from different camel breeds in Saudi Arabia. Saudi J. Biol. Sci. 19:177-183. https://doi. org/10.1016/j.sjbs.2011.12.002

Shazly, A. B., Z. He, M. A. El-Aziz, M. Zeng, S. Zhang, F. Qin, \& J. Chen. 2017. Fractionation and identification of novel antioxidant peptides from buffalo and bovine casein hydrolysates. Food Chem. 232: 753-762. https://doi. org/10.1016/j.foodchem.2017.04.071

Silveira, D., A. M. M. F. de Melo, P. O. Magalhães, \& Y. M. Fonseca-Bazzo. 2017. Tabernaemontana species:
Promising sources of new useful drugs. Studies in Natural Products Chemistry. 54:227-289. https://doi.org/10.1016/ B978-0-444-63929-5.00007-3

Thekkilaveedu, S., V. Krishnaswami, D. P. Mohanan, S. Alagarsamy, S. Natesan, \& R. Kandasamy. 2019. Lactic acid-mediated isolation of alpha-, beta- and kappa-casein fractions by isoelectric precipitation coupled with cold extraction from defatted cow milk. Int. J. Dairy Technol. 73:31-39. https://doi.org/10.1111/1471-0307.12646

Whitney, R. M., J. R. Brunner, K. E. Ebner, H. M. Farrell Jr., R. V.Josephson, C. V. Morr, \& H. E. Swaisgood. 1976. Nomenclature of the Proteins of Cow's Milk: Fourth Revision. J. Dairy. Sci. 59:795-815. https://doi.org/10.3168/ jds.s0022-0302(76)84280-4

Xu, Y., D. Liu, H. Yang, J. Zhang, X. Liu, J. M. Regenstein, Y. Hemar, \& P. Zhou. 2016. Effect of calcium sequestration by ion-exchange treatment on the dissociation of casein micelles in model milk protein concentrates. Food Hydrocoll. 60: 59-66. https://doi.org/10.1016/j.foodhyd.2016.03.026 